\title{
The study on the participation of Korean dentists in public posts
}

\author{
Ja-Won $\mathrm{Cho}^{1}$ and Su-Hyun Shim ${ }^{2 *}$ \\ ${ }^{1}$ Department of Preventive Dentistry, College of Dentistry, Dankook University, Cheonan 31116, Republic of Korea \\ ${ }^{2}$ Department of Dental Hygiene, Kyungbok University, Pocheon 11138, Republic of Korea
}

(Received Jul 26, 2017; Revised version received Sep 7, 2017; Accepted Sep 11, 2017)

\begin{abstract}
There have been few reports about the manpower planning of dentists in the public sector in Korea. The purpose of this study was to research dentists' opinions about the public posts, and to suggest public health policies for the new dental manpower position. A total of 536 dentists were asked to fill out questionnaires inquiring about their opinions of public posts. We used an online survey methodology to involve 500 participants. The chi-square tests and frequency distributions were implemented to analyze the dentists' opinions about the public posts. The significance level of 0.05 was applied. A statistical package SPSS 21.0 was used for the analysis. An overwhelming majority of dentists $(95.6 \%)$ answered that it is necessary to set up public posts for dentists. Respondents pointed out that the Korean Dental Association (35.5\%) and the Ministry of Health and Welfare (33.2\%) were the main institutes that should carry out this process. Especially, $47.4 \%$ of dentists answered they would quit their job if they had opportunities to fill public posts. Most dentists wanted to work as administrative officials (36.3\%) in the public sector. Many dentists $(62.4 \%)$ wanted to contribute to public welfare as health care professionals in public posts. Most of all, respondents (95.6\%) answered that it is imperative to improve the manpower system of dentists in public posts.
\end{abstract}

KEY WORDS: Dentists, Policy, Public health

\section{서 론}

현대에 들어서 경제 성장에 따른 의료수요의 급격한 증 가에 따라 많은 의료시설들이 세워졌다. 그러나 우리나라 의 의료시설은 주로 도시지역에 설치되었으며, 주체별로 는 의료기관 수 기준 공공병원 비중이 2014년 5.7\%로 공 공부문의 취약성이 크게 나타나고 있다[1]. 이외에도 전반 적인 의료 인력의 양적인 수급 문제, 의료인력 간 상대적 불균형 분포 등이 우리나라 보건의료인력의 현안으로 지 적되고 있다[2]. 보건복지부 의료인력 면허 등록 상황을 보면 의사와 치과의사 수는 2004 년 각각 81,998 명, 20,772 명에서 2014년 112,476명, 28,134명으로 10년 사이 약 $40 \%$ 가량 증가하였고 더불어 사회 여건의 변화, 그에 따 른 의식 변화 등에 따라 2000 년대에 들어서며 의료 서비 스는 다양한 변화를 겪고 있다[3].

*Corresponding author: Su-Hyun Shim

Department of Dental Hygiene, Kyungbok University, 154 Sinpyeong-ro, Pocheon 11138, Republic of Korea

Tel.: +82-31-539-5234, Fax: +82-31-539-5348

E-mail: noblige121@naver.com
이러한 변화 속에서 치과계 내에서도 운영의 효율성을 높이기 위하여 의료기관을 합병하거나 네트워크 형태를 취하여 대형화·전문화 하려는 노력을 기울여왔다[4]. 그럼 에도 불구하고 2016년 건강보험심사평가원의 상반기 진료 비 통계지표에 따르면, 임상진료를 시행하는 치과의사 중 $83.6 \%$ 에 해당하는 20,129 명이 치과의원에 몸담고 있어 치 과의원이 치과의사들의 주된 근무형태임을 알 수 있다. 이 에 반해, 의사의 경우 전체 진료인력 97,575 명 중 $22.2 \%$ 에 해당하는 21,697 명이 상급종합병원에, $19.9 \%$ 에 해당하 는 19,389 명이 종합병원에 근무하고 있어 $42.1 \%$ 가 종합병 원 이상의 기관에서 근무하고 있고, 그 밖의 보건기관 및 병원 급이 아닌 의원에 종사하는 의사는 38,381 명으로 $39.3 \%$ 에 그쳤다[5].

이와 같이 보다 폭넓은 연구와 경험을 쌓을 수 있는 병 원 급 이상의 의료기관 혹은 다양한 보건 관련 기관에 근 무하는 치과의사가 많지 않은 현실에서, 치과의사들이 중 장기적으로는 병원 급을 비롯한 다양한 분야로의 진출에 적극적으로 나서야 할 필요성이 점점 증가하고 있다[6]. 치과의사 인력수급에 관한 연구에 의하면, 이미 2020년 이 후 치과의사의 공급 초과가 예측되었고[7], 아직까지는 국 내 치과대학 및 치의학 전문대학원 정원에 비해 소수이기 
는 하나 매년 해외에서 유입되는 치과의사의 수도 증가하 고 있는 추세이다[8]. 또한 치의학 전문대학원 제도를 통 해 다양한 배경 전공을 갖춘 치과의사들이 배출됨에 따라 이제 치과의사들도 개원 외의 다양한 진로를 모색할 여건 이 성숙되었다.

그 중 공직은 업무의 사회 공헌적 성격상 보건 복지 분 야의 전문가로서 치과의사의 활발한 진출이 필요한 직종 이다. 직위에 따라 다르겠지만, 공직은 정책 개발이나 대 민 업무를 통해 임상의로서는 경험하기 힘든, 사회적 영향 력을 발휘할 수 있다는 장점도 가진다. 그렇지만 현재 치 과계에서 치과의사의 공직 진출에 관한 연구는 매우 부족 하다. 본 연구자들은 현재 치과의사들의 공직 진출 현황을 파악하고 이후 치과의사들의 활발한 공직 진출에 관한 방 안을 모색하는데 기초가 되고자 본 연구를 실시하였다. '공직'을 광의로 해석하면 교수직과 병원 급 근무자까지 포함 할 수 있겠으나, 본 연구에서는 조사 대상자인 '공직 치과의사'를 교수 및 공중 보건의를 제외한 보건소, 국공 립 및 시립병원 봉직 치과의사, 사무관 등의 보건직 공무 원 재직자로 제한하였다.

\section{연구대상 및 방법}

본 연구의 대상자는 치과의사 및 공직에 종사하는 치과 의사로 정하였다. 즉, 치과의사 대상자 조사는 치과의사들의 온라인 커뮤니티인 덴트포토 (http://www.dentphoto.com/) 설 문조사 센터를 통해 2014년 12월 19일 1일간 온라인으로 이루어졌으며, 500 명의 치과의사가 설문에 참여하면 프로 그램 상 자동으로 설문 조사를 닫도록 하였다. 공직에 종 사하는 치과의사는 '공공기관 치과의사회'의 2015년 3월 자 회원 명부를 바탕으로 2015년 4월부터 12월까지 설문 조사에 참여의사를 구두 또는 서면으로 명백히 밝힌 치과 의사를 대상으로 하였다.

2015년 3월 현재, ‘공공기관 치과의사회'는 교수와 공중 보건의를 제외한, 보건소, 국공립 병원 및 시립병원 재직 공무원 치과의사들의 유일한 단체이다. 조사 결과, 현재 이들 기관 외에 근무하는 공무원 치과의사들은 보건복지 부 등 중앙정부 부처에 근무하는 2 인 외에는 없어 사실상 '공공기관 치과의사회'회원들이 직업 공무원 치과의사들 의 전수라 할 수 있었다. 때문에 본 연구에서는 공직 치과 의사 대상자를 '공공기관 치과의사회' 회원으로 규정하였 다. 기관 당 평균 1 명 선인 치과의사 수를 감안할 때 '공 공기관 치과의사회'의 가입 대상자 수가 절대적으로 적고, 이 중 단기 근무 후 이직하는 회원이 수시로 있어 조사 시 점의 총 회원 수는 69 명으로 제한적이었다. 여기에 본 조 사에서는 현재 공직이 아닌 특별 회원 5 인을 제외한 64 명
의 회원 중, 설문에 동의하지 않거나 조사원이 연락했을 때 퇴직한 회원을 다시 제외한 최종 36 명의 설문지를 분 석하였다. 다만, 기존 직에서 퇴사하였으나 간호학과 교수, 치위생과 교수, 보건소 행정직 과장 등으로 재직하고 있는 7 명은 '공직 치과의사'의 범주로 보고 설문 조사를 실시하 였다. 방법은 회수율을 높이고자 '공공기관 치과의사회'로 부터 회원 명부를 받아 조사자가 직접 대상자를 방문해 설 문지를 전달하는 방식을 취하였다. 이와 같은 대인 설문 조사를 원칙으로 하였고, 조사자의 직접 방문을 원치 않는 경우에 한해 이메일을 통해 설문지를 보내는 온라인 설문 법을 활용하였다.

치과의사 대상 설문지는 연령, 성별, 현 근무처, 결혼 여 부, 건강 상태, 희망 근무지, 최종 학력, 수련 여부, 임상 경력을 묻는 인구사회학적 질문과 치과의사로서의 앞으로 의 근무 계획, 치과의사의 공직 진출에 관한 의견을 묻는 총 6 개의 문항으로 구성되었다. 공직 치과의사 대상 설문 지 역시 인구사회학적 질문과 앞으로의 근무 계획을 묻는 문항을 포함하였다. 이에 더해 공직 치과의사들의 설문지 는 공직 만족도 및 애로 사항 등 현재의 공직 생활과 치 과의사의 공직진출에 관한 의견을 묻는 총 14 개의 문항으 로 구성되었다.

수집된 자료의 데이터분석은 SPSS 21.0(IBM. NY, $\mathrm{USA}$ )을 이용해서 빈도분석과 카이스케어 검정을 시행하 여 응답 항목들 간의 연관성을 검증하였고 $P<0.05$ 인 경우 에 통계적 유의성이 있는 것으로 판정하였다. 또한 본 조 사에 관한 연구윤리는 단국대학교 기관생명윤리위원회의 승인을 받았다(IRB: DKU 2014-12-001).

\section{결 과}

Table 1 에 의하면 500 명의 치과의사 그룹에서 현 근무처 는 치과의원급이 465 명 $(93.0 \%)$ 으로 대다수를 차지했고, 직위 역시 단독 개원의가 360 명 $(72.0 \%)$ 으로 다수를 차지 했다. 임상 경력을 묻는 문항에는 6 10년 미만이 168 명 (33,6\%), 10 15년 미만이 157명(31.4\%)으로 다수를 차지 했다. 이외에도 희망 근무지역은 서울이 201 명 $(40.2 \%)$ 으 로 가장 많았고 경기도가 77명(15.4\%)으로 뒤를 이었다. 응답자의 현 거주지 역시 서울이 167 명 $(33.4 \%)$, 뒤이어 경 기도가 100 명(20.0\%)을 차지했다.

치과의사 그룹과 공직 치과의사 그룹간의 공통 질문이 었던 공직에 대한 견해에 관한 비교는 Table 2 에 정리되었 다. 앞으로의 근무계획을 묻는 질문에 치과의사 그룹의 $47.4 \%$ 의 치과의사가 임상의 대신 공직 치과의사를 택할 수 있다고 답했으며, 공직 치과의사 그룹에서는 $83.3 \%$ 가 공직 치과의사직을 계속 수행하겠다고 밝혀 공직 치과의 
Table 1. Sociodemographic distribution profiles of the dentists $(\mathrm{N}=500)$

\begin{tabular}{|c|c|c|}
\hline Variable & $\mathrm{N}$ & $\%$ \\
\hline \multicolumn{3}{|l|}{ Gender } \\
\hline Male & 401 & 80.2 \\
\hline Female & 99 & 19.8 \\
\hline \multicolumn{3}{|l|}{ Age } \\
\hline $20 \sim 39$ & 287 & 57.4 \\
\hline $40 \sim 49$ & 174 & 34.8 \\
\hline$\geq 50$ & 36 & 7.2 \\
\hline No answer & 3 & 0.6 \\
\hline \multicolumn{3}{|l|}{ Workplace } \\
\hline Dental clinic & 465 & 93.0 \\
\hline Dental hospital & 11 & 2.2 \\
\hline General hospital & 12 & 2.4 \\
\hline University hospital & 5 & 1.0 \\
\hline Temporary lay-off & 7 & 1.4 \\
\hline \multicolumn{3}{|l|}{ Types of employment } \\
\hline Practitioner (single) & 360 & 72.0 \\
\hline Practitioner (group) & 36 & 7.2 \\
\hline Employed doctor & 83 & 16.6 \\
\hline Public official & 15 & 3.0 \\
\hline Others & 6 & 1.2 \\
\hline \multicolumn{3}{|l|}{ Marriage } \\
\hline Yes & 422 & 84.4 \\
\hline No & 78 & 15.6 \\
\hline \multicolumn{3}{|l|}{ Health condition } \\
\hline Excellent & 44 & 8.8 \\
\hline Good & 147 & 29.4 \\
\hline Moderate & 275 & 55.0 \\
\hline Poor & 25 & 5.0 \\
\hline Very poor & 9 & 1.8 \\
\hline \multicolumn{3}{|l|}{ Educational level } \\
\hline Bachelor's degree & 250 & 50.0 \\
\hline Master's degree & 175 & 35.0 \\
\hline Ph. D & 72 & 14.4 \\
\hline No answer & 3 & 0.6 \\
\hline \multicolumn{3}{|l|}{ Training } \\
\hline Yes & 160 & 32.0 \\
\hline No & 340 & 68.0 \\
\hline \multicolumn{3}{|l|}{ Clinical experience (y) } \\
\hline$\leq 5$ & 66 & 13.2 \\
\hline $6 \sim 9$ & 168 & 33.6 \\
\hline $10-14$ & 157 & 31.4 \\
\hline $15 \sim 19$ & 61 & 12.2 \\
\hline$\geq 20$ & 48 & 9.6 \\
\hline
\end{tabular}

사의 공직 선택 비율이 압도적으로 높았다 $(P<0.001)$. 또한 공직 치과의사 그룹에서는 공직에 치과의사 직 개설 및 정 원 확대가 불필요하다는 의견이 한 건도 없었으며, 치과의 사 그룹에서도 22 명 $(4.4 \%)$ 을 제외한 478 명 $(95.6 \%)$ 의 응답 자가 공직에 치과의사 직 개설 및 정원 확대의 필요성을 인정했다. 공직 진출의 적정 연령대를 묻는 문항에는 치과
의사 그룹에서는 50 대 $(24.2 \%)$ 의 중장년층의 진출도 긍정 적으로 보았으나, 공직 치과의사들은 주로 30 대(58.3\%), 40대(36.1\%)의 젊은 나이에 공직에 진출하는 것을 바람직 하게 생각하는 것으로 나타났다. 즉, 치과의사 그룹의 조 사 결과와 달리 공직 치과의사들은 50 대 이후 공직 진출 에 대해서는 단 한 명도 찬성하지 않아 두 그룹간의 공직 진출 적정 연령에 관한 분명한 견해 차이를 보였다 $(P=0.001)$.

치과의사 그룹에게 복수 응답이 가능했던 2 개의 문항 중, 공직에 치과의사 직 개설 및 정원 확대를 추진할 기관 으로 대한치과의사협회(355명)와 보건복지부(332명)가 가 장 많이 지목되었고, 각 치과대학(139명)과 국회(157명)라 고 대답한 응답자들도 상당수 조사되었다(Table 3). 역시 복수 응답이 가능했던 진출 희망하는 공직 직종에 관해서 는 보건직 공무원(사무관 등)이 314 명으로 가장 높게 조사 되었고, 뒤이어 국공립 병원 취업 희망이 258 명, 보건소와 대학교수직 희망도 각각 147 명과 146 명으로 나타났다 (Table 4). 그 외에도 치과의사 그룹에서는 공직에 진출하 려는 이유를 묻는 문항에 보건 복지 정책 분야의 전문가 인 치과의사의 공직 진출이 필요해서라고 답한 응답자가 312 명 $(62.4 \%)$ 을 차지했고, 임상 분야에서의 치과의사 인 력의 포화 때문에 공직에 진출하려 생각한다는 응답자도 155 명(31.0\%)에 달했다. 기타 의견으로는 사회 공헌과 후 속 세대 교육을 위해 공직에 진출하겠다는 의견 등이 있 었다.

치과의사 그룹 중 공직 진출 적정 연령대(20 30대, 40 대 이상)에 대한 견해는 응답자의 연령에 따라서 유의한 차이 를 나타내지 않았고, 전 연령층에서 20 30대와 40대 이상 공직 진출에 대해 고른 지지를 나타내었다 $(P=0.510)$. 그러 나 응답자의 결혼 여부에 따라 공직 치과의사 직 개설 및 정원 확대에 관한 의견에는 차이를 보였는데, 미혼자에 비 해 기혼자가 공직에 치과의사 직 개설 및 정원 확대에 적 극적이었다(Table 5).

진출 희망 직종에서 보건소를 택한 응답자들은 연령대 별 유의한 차이를 나타내었다(Table 6). 즉, 연령이 높은 응답자일수록 타 공직보다 보건소를 택한 경우가 많았다.

또한 수련 여부에 따라 수련 받은 치과의사들의 경우는 국공립 병원 근무를, 이에 비해 수련 받지 않은 치과의사 들은 보건소 근무를 선호하는 것으로 조사되었다(Table 7).

공직 치과의사 그룹에서 성별은 남성이 9 명 $(25.0 \%)$, 여 성이 27명(75.0\%)으로 조사되었다. 연령은 20 39세가 5명 (13.9\%)으로 가장 적었고, 40 49세가 18 명(50.0\%), 50세 이상이 13 명(36.1\%)으로 조사되었다. 현 근무처는 보건소 가 23명 $(63.9 \%)$ 으로 다수였고, 국공립 병원 및 시립병원에 근무하는 치과의사가 7 명 $(19.4 \%)$ 으로 나타났다. 고용 형 태는 정규직과 비정규직이 각각 18 명 $(50 \%)$ 으로 조사되었 
Table 2. Opinions regarding the public posts $(\mathrm{N}=536)$

\begin{tabular}{|c|c|c|c|c|c|}
\hline \multirow{2}{*}{ Variable } & \multicolumn{2}{|c|}{ Dentists $(\mathrm{N}=500)$} & \multicolumn{2}{|c|}{ Dentists in public sector $(\mathrm{N}=36)$} & \multirow{2}{*}{$* P$-value } \\
\hline & $\mathrm{N}$ & $\%$ & $\mathrm{~N}$ & $\%$ & \\
\hline \multicolumn{6}{|l|}{ Future career plans } \\
\hline Clinician & 263 & 52.6 & 6 & 16.7 & \multirow{2}{*}{$<0.001$} \\
\hline Public official & 237 & 47.4 & 30 & 83.3 & \\
\hline \multicolumn{6}{|c|}{ Necessity of public posts } \\
\hline Very necessary & 214 & 42.8 & 24 & 66.7 & \multirow{5}{*}{0.076} \\
\hline Necessary & 185 & 37.0 & 9 & 25.0 & \\
\hline Moderate & 79 & 15.8 & 3 & 8.3 & \\
\hline Unnecessary & 11 & 2.2 & 0 & 0 & \\
\hline Very unnecessary & 11 & 2.2 & 0 & 0 & \\
\hline \multicolumn{6}{|c|}{ Optimal age in public posts } \\
\hline $20 \mathrm{~s}$ & 19 & 3.8 & 2 & 5.6 & \multirow{5}{*}{0.001} \\
\hline $30 \mathrm{~s}$ & 153 & 30.6 & 21 & 58.3 & \\
\hline $40 \mathrm{~s}$ & 186 & 37.2 & 13 & 36.1 & \\
\hline $50 \mathrm{~s}$ & 121 & 24.2 & 0 & 0 & \\
\hline $60 \mathrm{~s}$ & 21 & 4.2 & 0 & 0 & \\
\hline
\end{tabular}

* $P$-value determined by chi-square test.

Table 3. Institutes deemed to be responsible for the entry of dentists in public posts (Multiple responses)

\begin{tabular}{lc}
\hline \multicolumn{1}{c}{ Institute } & $\%(\mathrm{~N})$ \\
\hline Korean Dental Association & $35.5(355)$ \\
Dental school & $13.9(139)$ \\
National Assembly & $15.7(157)$ \\
Ministry of Health and Welfare & $33.2(332)$ \\
Others & $1.7(17)$ \\
\hline
\end{tabular}

Table 4. Types of public posts (Multiple responses)

\begin{tabular}{lc}
\hline \multicolumn{1}{c}{ Public posts } & $\%(\mathrm{~N})$ \\
\hline Public health center & $16.9(147)$ \\
Administrative official & $36.3(314)$ \\
Public hospital & $29.7(258)$ \\
Professor & $16.8(146)$ \\
Others & $0.3(3)$ \\
\hline
\end{tabular}

Table 5. Opinions for public posts by marital status* $(\mathrm{N}=500)$

\begin{tabular}{lccr}
\hline Opinion \Marital status & $\begin{array}{c}\text { Single } \\
\text { N (\%) }\end{array}$ & $\begin{array}{c}\text { Married } \\
\text { N (\%) }\end{array}$ & Total \\
\hline Very necessary & $28(35.9)$ & $186(44.1)$ & 214 \\
Necessary & $29(37.2)$ & $156(37.0)$ & 185 \\
Moderate & $12(15.4)$ & $67(15.9)$ & 79 \\
Unnecessary & $4(5.1)$ & $7(1.7)$ & 11 \\
Very unnecessary & $5(6.4)$ & $6(1.4)$ & 11 \\
Total & 78 & 422 & 500 \\
\hline
\end{tabular}

* $P$-value determined by chi-square test, $P=0.017$

다. 그 밖에도 정규직 중 4급 이상 공무원은 5명(13.9\%), 5 급 공무원 10 명(27.8\%), 6 급 공무원은 3 명 $(8.3 \%)$ 으로 나타
Table 6. Public health center preference according to age* $(\mathrm{N}=497)$

\begin{tabular}{lcccc}
\hline \multirow{2}{*}{ Preference $\backslash$ Age } & $20 \sim 39$ & $40 \sim 49$ & $50 \leq$ & \multirow{2}{*}{ Total } \\
& $\mathrm{N}(\%)$ & $\mathrm{N}(\%)$ & $\mathrm{N}(\%)$ & \\
\hline Others & $216(75.3)$ & $114(65.5)$ & $22(61.1)$ & 352 \\
Public health center & $71(24.7)$ & $60(34.5)$ & $14(38.9)$ & 145 \\
Total & 287 & 174 & 36 & 497 \\
\hline *P-value determined by chi-square test, $P=0.034$
\end{tabular}

Table 7. Public posts preference by training experience $(\mathrm{N}=500)$

\begin{tabular}{lcccc}
\hline Preference $\backslash$ Training & $\begin{array}{c}\text { Trained } \\
\text { N (\%) }\end{array}$ & $\begin{array}{c}\text { Not trained } \\
\text { N (\%) }\end{array}$ & Total & *P-value \\
Others & $128(80.0)$ & $225(66.2)$ & 353 & \\
Public health center & $32(20.0)$ & $115(33.8)$ & 147 & 0.002 \\
Total & 160 & 340 & 500 & \\
\hline Others & $65(40.6)$ & $177(52.1)$ & 242 & 0.017 \\
Public hospital & $95(59.4)$ & $163(47.9)$ & 258 & \\
Total & 160 & 340 & 500 & \\
\hline
\end{tabular}

*P-value determined by chi-square test.

났다. 결혼 여부에 있어서는 33 명 $(91.7 \%)$ 의 응답자가 기혼이 라고 답했고, 공직 재직 연수를 묻는 문항에는 6년 이상이라 고 답한 응답자가 32명(88.9\%)을 차지했다(Table 8).

공직 생활 만족도에 있어서는 3 명 $(8.3 \%)$ 의 응답자를 제 외한 33명(91.7\%)이 대체로 만족한다고 답했다.

\section{교 찰}

본 연구는 과거와는 달라진 의료 및 사회 환경 속에서 
Table 8. Sociodemographic distribution profiles of the dentists in public posts $(\mathrm{N}=36)$

\begin{tabular}{|c|c|c|}
\hline Variable & $\mathrm{N}$ & $\%$ \\
\hline \multicolumn{3}{|l|}{ Gender } \\
\hline Male & 9 & 25.0 \\
\hline Female & 27 & 75.0 \\
\hline \multicolumn{3}{|l|}{ Age } \\
\hline $20 \sim 39$ & 5 & 13.9 \\
\hline $40 \sim 49$ & 18 & 50.0 \\
\hline$\geq 50$ & 13 & 36.1 \\
\hline \multicolumn{3}{|l|}{ Workplace } \\
\hline Public hospital & 7 & 19.4 \\
\hline Public health center & 23 & 63.9 \\
\hline Others & 6 & 16.7 \\
\hline \multicolumn{3}{|l|}{ Types of employment } \\
\hline Permanent employment & 18 & 50.0 \\
\hline Temporary employment & 18 & 50.0 \\
\hline \multicolumn{3}{|l|}{ Marriage } \\
\hline Yes & 33 & 91.7 \\
\hline No & 3 & 8.3 \\
\hline \multicolumn{3}{|c|}{ Working period in public posts (y) } \\
\hline$\leq 5$ & 4 & 11.1 \\
\hline $6 \sim 9$ & 10 & 27.8 \\
\hline $10 \sim 14$ & 9 & 25.0 \\
\hline $15 \sim 19$ & 7 & 19.4 \\
\hline$\geq 20$ & 6 & 16.7 \\
\hline \multicolumn{3}{|l|}{ Job satisfaction } \\
\hline Very satisfied & 3 & 8.3 \\
\hline Satisfied & 18 & 50.0 \\
\hline Moderate & 12 & 33.4 \\
\hline Dissatisfied & 3 & 8.3 \\
\hline Extremely dissatisfied & 0 & 0 \\
\hline
\end{tabular}

치과의사들의 다양한 분야로의 진출이 필요하다는 전제에 서 출발하였다. 이미 앞선 연구에서, 치과 의료의 특성상 치과의원 종사자 비율이 높은 것을 감안하더라도, 지나친 단독 개원으로의 쏠림 현상은 여러 부작용을 일으키는 점 이 지적되었다. 즉, 치과의원간의 경쟁을 격화시키고, 종합 병원 이상의 의료기관에서 치과 부분의 약화와 연구 및 개 발 기능을 수행할 수 있는 대형 치과병원의 존립마저 어 렵게 할 수 있다는 것이다[6]. 아울러 의사의 경우에는 개 원 외에도 병원 급 근무자 비율이 높은 점에 착안하여, 본 연구자들은 치과의사들의 다양한 진로에 대한 연구를 기 획하게 되었다. 특히 첫 결과물인 금번 연구에서는 치과의 사가 진출할 수 있는 공직을 염두에 두고, 당사자인 치과 의사 536명에게 공직 진출에 대한 수요 및 각 그룹별 세 분화된 의견 등을 수집·분석하였다.

Table 2에서 치과의사로서의 앞으로의 근무 계획을 묻는 질문에 공직 치과의사 그룹에서는 $83.3 \%$ 가 공직 치과의사 직을 계속 수행하겠다고 밝혔고, 치과의사 그룹에서는
$47.4 \%$ 의 치과의사가 공직의 기회가 주어지면 임상의 생활 을 그만둘 수 있다고 응답했다. 특히 치과의사 그룹의 답 변은, 2009년 대한공공치의학회('공공기관 치과의사회‘의 전신)가 전국 치과의사를 대상으로 덴트포토에 의뢰해 실 시한 설문조사[6,9]에서 응답자 중 $34 \%(1,186$ 명 $)$ 가 보건복 지부나 시군구 지방자치단체 및 보건소에서 정규 공무원 으로 근무할 의사가 있다고 답한 것보다 높아진 비율을 나 타냈다.

일반 치과의사 그룹의 조사 결과와 비교해 볼 때, 공직 치과의사 그룹에서는 공직 진출에 더 적극적이었고 특히 50 대 이후보다는 이른 나이에 공직에 진출하여야 한다고 생각하고 있는 것으로 나타났다. 즉, 공직 치과의사 그룹 에서는 50 대 이후의 공직 진출을 지지하는 응답자는 한 명도 없었지만, 치과의사 그룹에서는, 50 대도 공직 진출의 적정 연령이라고 답한 응답자가 $24.2 \%$ 에 이르고 있었다. 이는 실제 공직 생활을 경험한 치과의사들의 경우, 은퇴가 가까운 50 세 이후의 치과의사들 보다는 젊은 치과의사들 이 일찍 공직에 진출해야 한다는 인식이 확고한 반면, 공 직 경험이 없는 일반 치과의사들의 상당수는 여전히 공직 을 은퇴 연령에서 모색해 볼만한 대안으로 여기고 있기 때 문으로 분석된다. 이를 참고하여 그간 상대적으로 진출이 적었던 젊은 층의 공직 진출 모색에 초점을 맞춘 연구도 필요해 보인다. 다시 말하여, 젊은 층의 공직 유입을 도모 하는 정책과 이에 따른 일선 치과대학 및 치의학 전문대 학원에서의 교육 과정 개편 등도 함께 필요할 것으로 분석 된다. 또한 치과의사 그룹에서는 압도적인 $95.6 \%(478$ 명)의 응답자가 공직에 치과의사 직 개설 및 정원 확대에 관해 그 필요성을 인정했다(Table 2).

Table 3에 따르면 치과의사들은 이를 추진할 기관으로는 대한치과의사협회(35.5\%), 보건복지부(33.2\%)의 순으로 꼽았다. 따라서 향후 대한치과의사협회에서는 대한의사협 회 등의 유관 단체의 선례를 참고하여 보건복지부, 공무원 의 인원을 실제로 조정하는 행정자치부, 지방자치단체 등 과 협의하여 관련 정책을 발의할 필요가 있겠다.

특히 본 연구에서 주목하는 점은, 공직 중에서도 공공병 원에서의 임상의로서의 공직이 아니라 보건 행정가로서의 공직에 대한 수요가 가장 높았다(36.3\%)는 것이다(Table 4). 이는 치과의사들의 공직에 대한 관심이 이미 상당하며, 이러한 경향이 점점 증가될 것임을 보여준다. 때문에 이러 한 결과를 바탕으로 후속 연구에서는 이제 막연히 기회가 주어지면 공직에 진출할 의사가 있는가를 묻는 것이 아닌, 치과의사들이 공직 진출을 위해 어느 정도의 시간과 비용 투자를 할 수 있는지, 이를 위해 치과대학 혹은 치의학 전 문대학원에서 필요한 교육 과정과 대한치과의사협회 등 관계 기관의 지원이 필요한 부분은 어떤 것인지를 구체적 으로 조사하여 본 연구의 한계를 보완해야 할 것이다. 더 
불어 이번 결과로 교수직에 대한 수요도 적지 않은 것이 확인된 만큼, 후속 연구에서는 금번에‘공직‘의 범주에 포 함되지 않은 치과대학 및 치위생과 등 치과의사가 진출할 수 있는 교수직에 대한 추가 분석도 요구된다.

교차분석 결과, 치과의사 그룹에서는 연령과 성향에 따 라 진출 희망 공직 직종에도 차이를 나타냈다. 즉, Table 6 에 따르면 응답자의 연령이 높을수록 보건소를 선택한 경 우가 많았다 $(P=0.034)$. 그리고 Table 7에서와 같이 수련 받지 않은 치과의사들이 보건소 근무를 선호한데 반해, 수 련을 받은 치과의사들은 보건소를 택하지 않고 $(P=0.002)$ 국공립 병원 근무를 선호하는 경향이 뚜렷했다 $(P=0.017)$. 수련을 받은 치과의사들의 경우, 현행 1 차 진료 및 예방 업무 위주의 보건소 업무보다는 전문 분야 진료를 지속할 수 있는 병원 근무를 선호하는 것으로 보인다. 따라서 이 상의 결과를 바탕으로 앞으로 치과의사의 공직 진출과 관 련한 정책 수립 시에는 개개 치과의사의 연령별, 수련 여 부 및 임상 분야별 맞춤형 공직 진출에 대한 구체적인 계 획안이 마련될 필요가 있을 것으로 보인다.

Table 8 에 의하면 공직 치과의사 그룹의 근무처는 보건 소에 집중되어 있으며, 종사하는 치과의사 또한 여성 위주 로 구성되어 있었다. 또한 공직 치과의사들의 재직 연수는 6년 이상이 32 명 $(88.9 \%)$ 으로 비교적 장기근무를 하고 있 는 것으로 파악되었다. 공직 생활 만족도에 있어서는 3 명 (8.3\%)의 응답자를 제외하고 대체로 만족한다고 응답해 공직에 대한 치과의사들의 만족도도 매우 높은 편임을 알 수 있다. 종합해 보면, 공직이 비교적 양질의 일자리임에 틀림없고, 이의 확대에 치과계가 적극적으로 나설 당위성 이 있는 것으로 분석된다. 보다 긴 안목에서, 이러한 공직 진출을 위한 정책 개발 시 직역의 확장 방안과 남자 치과 의사들의 공직 유입이 적은 원인에 대한 분석 역시 필요 할 것이다.

본 연구에서는 향후 치과계에서 확장해야 할 공직의 현 종사자를 대상으로 의견을 수집하기 위해, 치과대학 교수 와 공중 보건의를 제외한 보건소, 국공립 병원 및 시립병 원 재직 치과의사로 구성된 '공공기관 치과의사회' 소속 회원을 대상으로 공직 치과의사 그룹의 설문 조사를 실시 하였다. 2015년 3월 현재, '공공기관 치과의사회'는 69 명 의 회원으로 구성되었다. 의사의 경우, 한 곳의 보건소나 국공립 병원에도 기관장을 비롯해 수 명에서 수십 명에 달 하는 정원을 확보하고 있으나, 치과의사들의 경우 이들 각 기관당 평균 1 명이 배치되어 있고, 치과의사 정원 없이 치 과위생사만으로 운영되는 보건소도 있어 대상자 수가 당 초의 예상보다 적었다. 금번 결과에는 이와 같이 유의성을 입증하기에는 대상자 수가 적어 포함되지 않았지만, 공직 치과의사 그룹을 대상으로 공직 생활의 애로 사항을 묻는 문항이 있었다. 이 문항에서 공직 치과의사들은 기타 의견
으로 국립 병원의 정규직(사무관, 서기관 등)의 양질의 일 자리가, 기존 치과의사의 퇴직 후 속속 의과의 정원으로 돌려지는 문제 등이 있음을 서술하였다. 치과의사들의 공 직 진출이 확대되어야 할 필요는 증가 하는데, 정작 일선 에서는 정원이 오히려 줄고 있는 상황이었다. 특히, 본 연 구 결과에 따르면 공직임에도 불구하고 이들 치과의사의 $50 \%$ 가 비정규직으로 조사되었고 정규직 중 4 급이나 5 급 공무원이 아닌 6 급 공무원도 3 명 $(8.3 \%)$ 으로 나타났다. 따 라서 향후 치과계에서는 공직에 치과의사 직 개설 및 정 원 확대와 더불어, 비록 소수이긴 하지만 현재 근무하고 있는 치과의사들의 처우 개선 및 정원 확보 노력도 함께 기울여야 할 것으로 파악되었다.

치과의사 그룹의 조사에서는 이외에도 공직 진출의 이 유에 대해서는 임상 분야에서의 치과의사 인력의 포화 때 문이라고 답한 응답자보다는 보건 복지 분야의 전문가로 서 치과의사의 공직 진출의 당위성에 과반이 넘는 $62.4 \%$ 의 응답자가 지지를 보냈고, 기타 의견으로 사회 공헌과 후속 세대 교육을 위해 공직에 진출하겠다는 의견 등이 있 었다. 이는 치과의사들이 공직에 관심을 갖는 것이 단지 경제적 이유나 명예 때문이 아니라는 것을 의미한다. 실제 공무원은 경제적인 보상보다는 국민을 책임지고 공익을 추구하는 공공 봉사와 사회 공헌에 가치를 두는 직업이라 볼 수 있다. 덧붙여 직에 따라 다르기는 하지만, 공직은 정 책 개발이나 대민 업무를 통해 임상의와 비교할 수 없는 사회적 영향력을 행사할 수 있는 장점이 있다. 따라서 본 연구를 통해 치과의사들의 이러한 사회 공헌에 대한 욕구 가 적지 않음을 발견한 것은 각별히 의미가 있는 소득이 었다.

직업 공무원 치과의사들의 의견을 수집하기 위해, 치과 대학 교수와 공중 보건의가 포함되지 않은 보건소, 국공립 병원 및 시립병원 재직 치과의사로 구성된 ‘공공기관 치과 의사회, 소속 회원을 대상으로 공직 치과의사 그룹의 설문 을 실시하여, 대상자의 수가 제한적이었던 점이 본 연구의 가장 큰 한계로 여겨진다. 또, 비록 분석 결과에 영향을 미 치지는 않았으나, 일반 치과의사 그룹의 인구사회학적 조 사에서 현재 공직에 종사한다고 답한 치과의사가 15 명이 있었는데, '공공기관 치과의사회' 회원 수와 비교해 보았 을 때 적지 않은 수이다. 이는 온라인 설문 보기에 예시된 단독 개원의, 공동 개원의, 월급·관리의, 휴직 중에 해당하 지 않는다고 생각한 교수나 공중보건의 등이 공직의를 선 택했을 가능성도 있는 만큼, 온라인 설문 시에는 혼동의 여지를 줄이는 설문 문항 개발과 충분한 설명이 이루어져 야 할 것으로 파악되었다. 아울러 본 연구를 통해서 공무 원 치과의사들의 의견을 최초로 정리해 본 것은 의의를 지 닌다 하겠지만, 저자들은 직업 공무원 치과의사의 수가 매 우 적어 모든 결과를 일반화하기엔 부족하다는 결론을 내 
렸다. 때문에 공직 치과의사를 대상으로 시행한 14 개 문항 중 유의미했던 일부만 본 논문에 싣기로 하였다. 따라서 후속 연구에서는 금번 연구를 바탕으로 교수 등을 포함하 여 공직 치과의사의 범위를 넓히고, 위에 언급된 문제점들 을 보완한 설문을 바탕으로 치과의사의 공직 진출에 대한 연구를 지속해 나갈 필요가 있겠다.

\section{결 론}

1. $95.6 \%(478$ 명 $)$ 의 치과의사가 공직에 치과의사 직 개설 및 정원 확대에 관해 그 필요성을 인정했다.

2. 이를 추진할 기관으로는 대한치과의사협회가 $35.5 \%$, 보건복지부 $33.2 \%$, 국회 $15.7 \%$, 치과대학(혹은 치의학 전 문대학원)이 $13.9 \%$ 를 차지하였다.

3. 치과의사로서의 앞으로의 근무 계획을 묻는 질문에 237 명(47.4\%)의 치과의사가 공직의 기회가 주어지면 임상의 생 활을 그만둘 수 있다고 밝혔다. 진출 희망하는 공직 직종에 관해서는 행정직에 해당하는 보건직 공무원(사무관등)이 $36.3 \%$ 로 가장 높게 조사되었다. 이 밖에 국공립 병원 $29.7 \%$, 보건소 $16.9 \%$, 대학 교수 $16.8 \%$ 순으로 나타났다.

4. 공직 진출의 이유에 대해서는 보건 복지 분야의 전문 가로서 치과의사의 공직 진출이 필요하다에 과반이 넘는 $62.4 \%$ 의 응답자가 지지를 보였다.

\section{감사의 글}

저자들은 본 연구에 참여한 모든 치과의사, 특히 열악한 여건에서 묵묵히 정진하고 계신 ‘공공기관 치과의사회' 소속 의 공무원 치과의사 선생님들께 감사와 경의를 표합니다.

\section{Conflict of Interest}

The authors declare that they have no competing interests.

\section{ORCID}

Ja-Won Cho 0000-0003-1458-0416

Su-Hyun Shim 0000-0002-8818-6473

\section{References}

1. Ministry of Health and Welfare. 2016 Data of public health. Sejong: Ministry of Health and Welfare, National Medical Center; 2016.

2. Oh YH. Changes in health care environment and ways to create jobs. In Health Welf Policy Forum 2010;162:2231.

3. Ministry of Health and Welfare. Ministry of health and welfare statistical year book 2015. Sejong: Ministry of Health and Welfare; 2015.

4. Kim YT, Shin DM. The effect of leadership and empowerment on the organizational effectiveness in independent dental clinics and network dental clinics. Korean J Bus Adm 2012;25:21-49.

5. Health insurance review $\&$ assessment service. 2016 Statistic indices of medical expenses. Seoul: Health insurance review \& assessment service; 2016.

6. Chang YI. Proposal for various social field participation of Korean young dentist. J Kor Dent Assoc 2011;49:7-14.

7. Shin HS, Hong SY. The supply and demand for dentists in Korea. Health Soc Welf Rev 2007;27:81-102.

8. Shin JW, Kim YJ, Kim KN, Kim KK, Lee JI. Quality assurance of dental care and appropriate supply of dentists in view of the increasing inflow of dental graduates from abroad. J Kor Dent Assoc 2017;55:7-20.

9. Daily dental. Policy Project, Policy Insurance [Internet]. Korean Dental Association; [cited 2017 May 22]. Available from: http://www.dailydental.co.kr/news/article.html? no $=64692$. 